潮汐周期を与えることができる飼育装置の一例

吉 岡 英 二

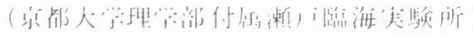

\title{
An example of the device for keeping animals under artificial tidal regimen.
}

\section{Eiji YOSHIOKA}

Seto Marine Biological Laboratory, Kyoto University.

はじめに

潮間带の生物は、潮汐運動により、水没と干出の周期的な環 境の変化にさらされている。そのために、潮間带の生物には潮 为周期に応した周期的な活動を小すものが多い。そのような活 動の生理的な機構を解析するためには、潮汐による楇期的な環
境の変化を室内で再現できる装置があれば、得るところが多い。 しかし、市販品ではてのような水槽は完られず、自作する以外 にない。

私は、ヒザラガイの産卵期間や産卵時刻を支配する要因を調 べる目的で、水槽内の水没・干出と明・暗を任意に制御できる 装置を自作した。人下、装置の概要と、製作と操作における

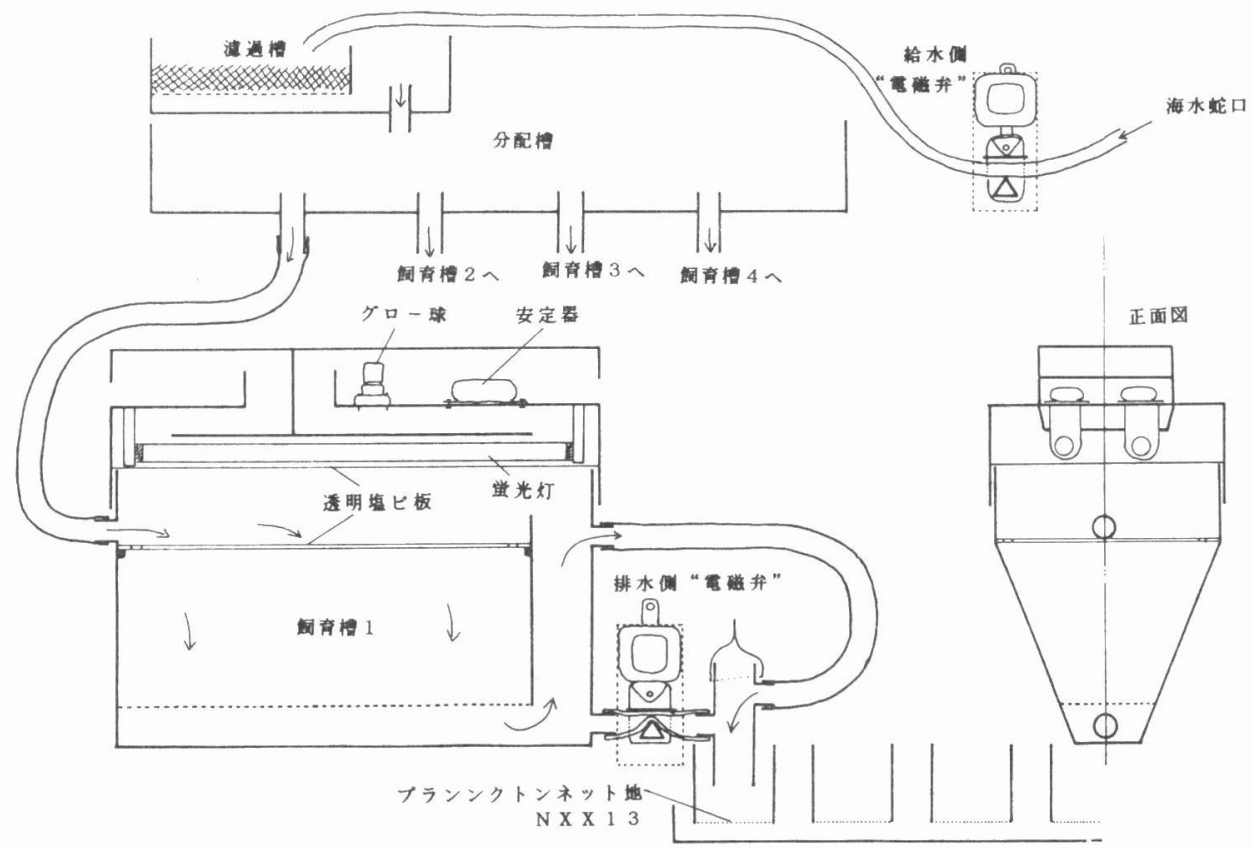

図 1 水槽と水路の概念汹。飼育槽 2 〜 は省略した。 
問題点について述へ、今後同じような装置の製作にあたっての 参考に供したい。

\section{水槽と水路}

この装置は、京都大学理学部付属瀬戸臨海実験所の小飼育室 で使用した。飼育室には、およそ $1 \mathrm{~kg} / \mathrm{cm}^{2} の$ 水压の海水が配管 されており、一つの蛇口からおよそ13に/分の給水が可能であ る。海水が蛇口から 4 つの水槽に分配され、排水されるまでの 水路の概略を図 1 亿示す。水槽への給水の制御は 1 ケ所でおこ なっているので、4つの水槽に対して別々の条件で給水するこ とはできない。一方、排水は、水槽ごとに制御できるようにな っている。水槽から排出される海水は、プランクトンネット地 NXX13によって甥され、水槽内に放出された浮游卵を水槽で とに集めるととができる。明暗の条件は 4 つの水槽に別々に与 えるととができる。

水槽と照明灯の部分は、主として 3 mm厚の硬質塩化ビニール 板で作った。蛍光灯と水槽の間は、とくに漏電に注意しなけれ ばならないので、塩ビ用接着剤とシリコンコーキング剤によっ て水もれを防いでいる。

各飼育水槽は $3,300 \mathrm{~cm}$ の飼育容樍を持つ。給水をはじめて約 2 分で満水になり、排水をはじめて約 1 分で水が抜ける。照明
には各水槽に15Wの䖢光灯 2 灯を使った。照明しないときには 槽内の明るさは 0,1 lx 以下だった。水を抜いて照明すると、水 槽底面でおよそ 5,500 exの照度となり、水槽内の温度は、室温 よりもおよそ $6{ }^{\circ} \mathrm{C}$ 高くなり安定する。

\section{給排水の制御}

水槽への給排水の制御は市販の電磁バルブを使っても可能だ が、高価で大がかりになるので、図2のような装置(自作“電 磁弁”) 在作った。この装置の中心にはソレノイド(国際電業 (株)製 SA-2502)を使っている。ソレノイドは電気エネル ギーを直線運動の機械的エネルギーに変換する。この装置が動 作しない状態では水路が開放されており、動作した状態ではり レノイドの吸引力によってシリコンチューブがはさみつけられ、 水路が断たれて水が止まる。ピンチコックによってゴムチュー

を閉じると同じ原理である。水路在断っている間は常に36 Wの電力を消費し、相当の発熱があるので、ソレノイドの周辺 の空気が流通しやすいように部品の形之設置場所を配慮した。

この装置が海水に接するのはシリコンチューブの内面だけな ので、シリコンチューブが破れない限り水もれが起こる可能性 はない。シリコンチューブは、海水に対して充分な耐食性があ り、装置が動作する時に生じる剪断力にも耐える。しかし、ゴ
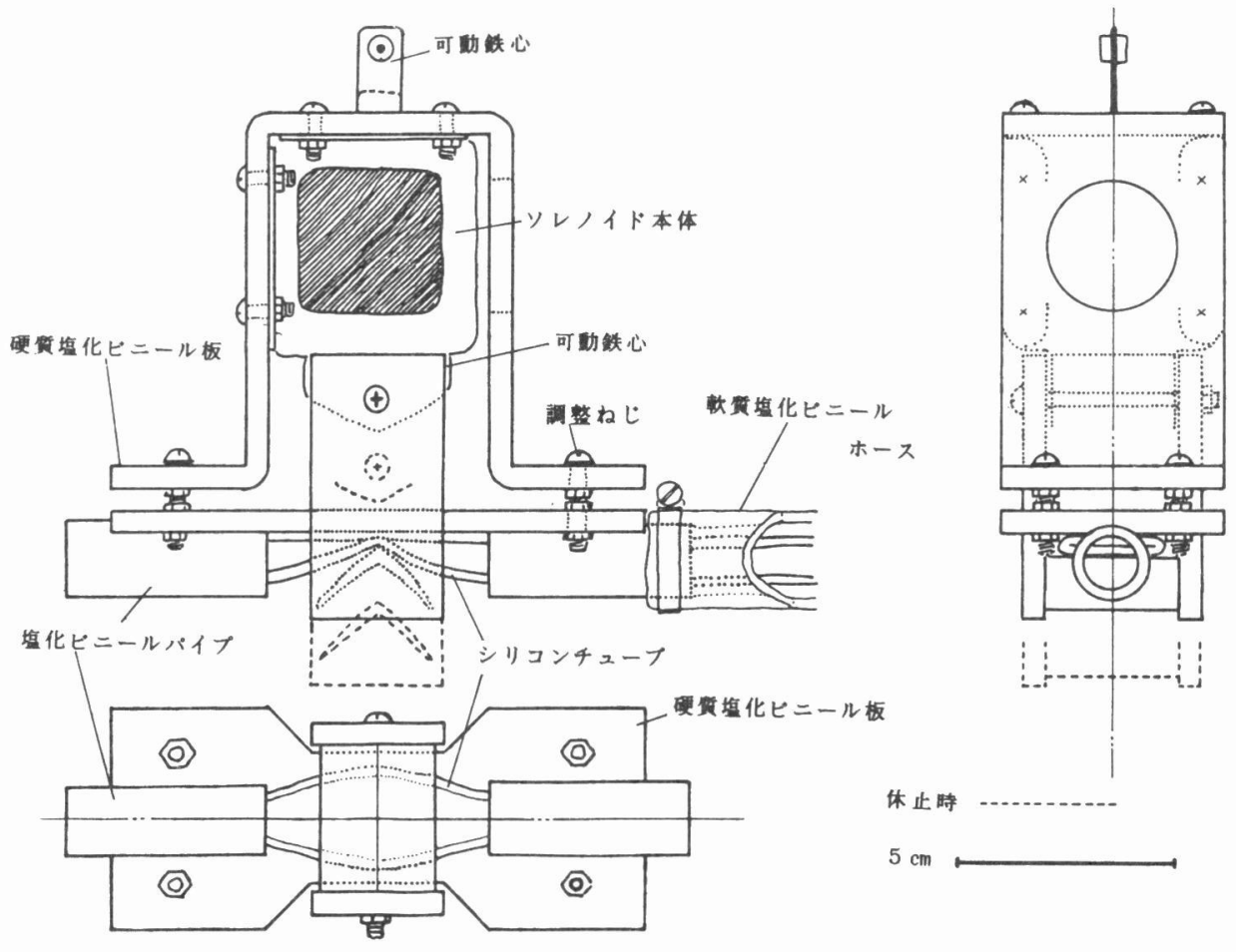

図2 給水側“電磁弁”。排水側のものは、シリコンチューブの径が異なる(本文参照)。 
ムチューブや軟質塩化ビニールホースでは、响食性や剪断ノに 対する耐久性が允分でなく、シリコンチューブの代扣りに使う ことはできない。

シリコンチューブは二種類の太さのものを用意しだ。水忙の

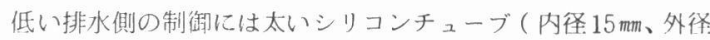
$20 \mathrm{~mm}$ ) 在用いて、早く排水できるようにした。水圧のある給水 側の制御には細いシリコンチューブ（内径 $10 \mathrm{~mm}$ 、外徍 $12 \mathrm{~mm}$ ) を用いて、ソレノイドの定格内の力で海水が完全に止まるよう に配慮した。今回製作した装嵁では、水压が高くなるほど、あ るいはシリコンチューブが太くなるはど、水路を忖めるために 大きな力が必要になる。給水側の装睢が制御する水路の水圧は およそ $1 \mathrm{~kg} / \mathrm{cm}$ であるが、太いシリコンチューブの“電磁弁” では完全に快めるとはできない。また、紐いシリコンチュー ブの“電磁开”在用いて、より水王の高い水道水などを完全に 止めるととはむずかしいと思われる。

$$
\text { コンピューターのタイマーとしての利用 }
$$

市販されているタイマーは、ふつう 24 時間周期で動作する。 しかし、潮为周期は約 13 時間周期であるので、潮汐楇期を再現 するのに市販のタイマーは利用しにくい。私は飼育装䈯全体を 制御するために、パーソナル・コンピューター、シャープMZ 一 $80 \mathrm{~K}$ 孝用いた。 $\mathrm{MZ}-80 \mathrm{~K}$ は队部に時計を持っており、タイ
マーのように争定した時刻に特定の動作をおこなおせることが でさる。プログラムによって、給排水を制御し潮汐周期に灾じ 動作:を㞣易に打てなわせることができる。

給排水を制御するンレノイドと照明用の敛光灯は父流 $100 \mathrm{~V}$

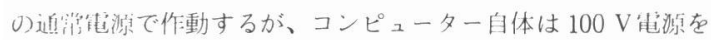

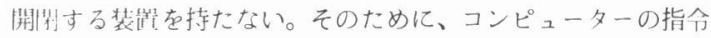
によって 100 V电淙老開閉するためのインターフェイスを作っ た。その構造や、製作にあたっての注意点などは、パソコンイ ンターフェイスについて書かれたアマチュア问けの解説書に詳 しいので、とてではその概略について为 3 に小すにとどめる。

\section{一運転の実際と問題点}

潮汐条件は捄よそ6時間 30 分でとに水没と干出をくり这すと とによって再現した。また、水没 $\rightarrow$ F出、干出 $\rightarrow$ 水没へ移る30 分間は、 1 分間の排水之 2 分間の給水をくり这すととによって 疑似的なAwash の状態を作った（図４）。それらの操作プロ グラム用の言語はB A S I Cを用いたが、動作速度やメモリ一空 間などに特に問題はおてらなかった。

この装置在使うことによって、潮汐周期のある飼育環境を比 較的長期にわたって㬰現しなければならない実験計画も谷易に 立てられるようになった。実際に90日間実験に使用したが、そ の間にリレーの制御部にハンダ付け不良による断線が数回生じ
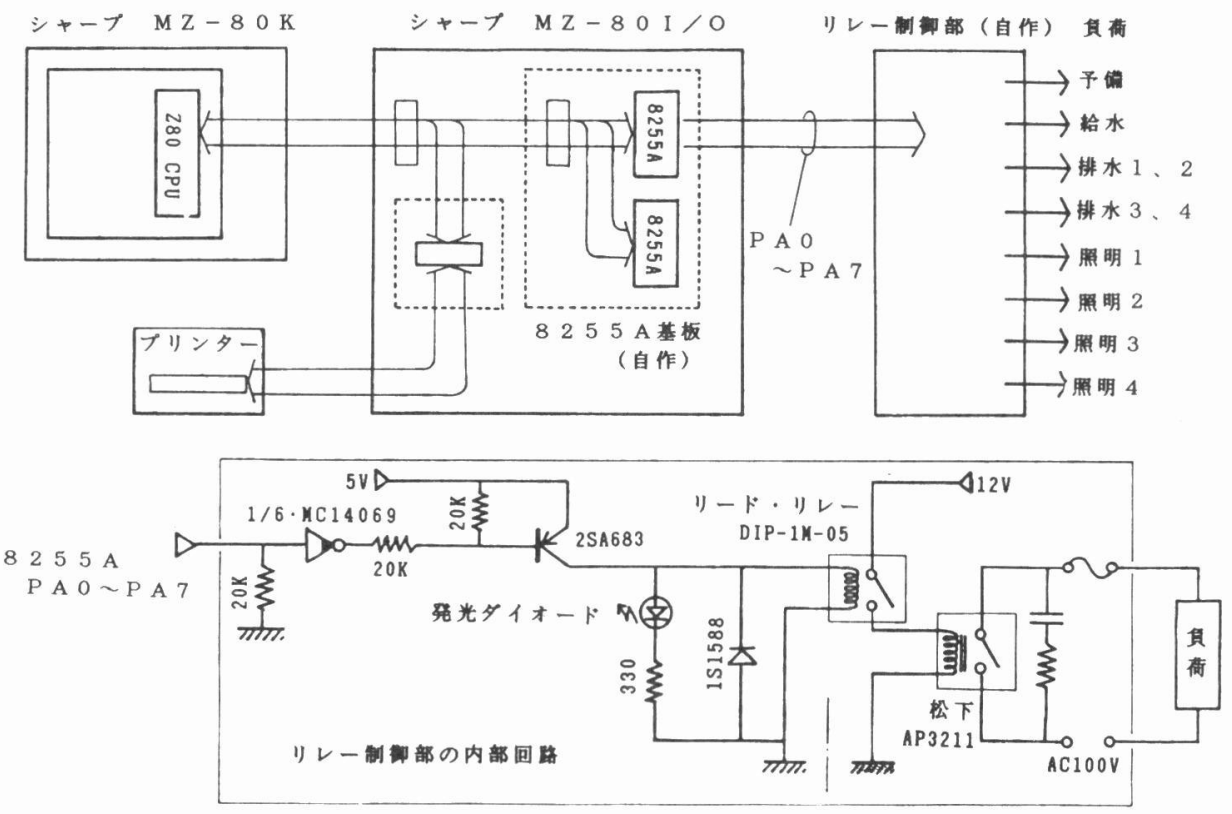

烕3 コンピューターによって、電灯線を開閉する装置の概略。 


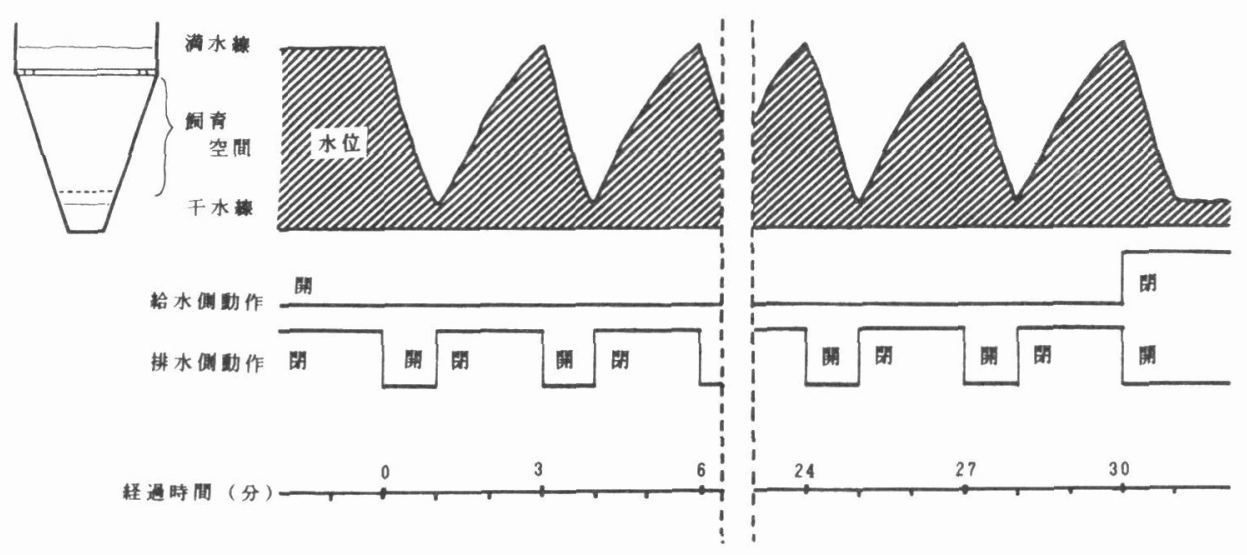

図 4 “水没 $\rightarrow$ 干出” の動作と水位の実際。

\section{ただけであった。}

今後解決しなければならない問題点について以下に述べる。 その1つは、干出した状態で照明すると槽内の気温が高くな るととである。室温が $30^{\circ} \mathrm{C}$ を越える夏の日中ならば、槽内の 気温が $40^{\circ} \mathrm{C}$ 近くまで上がることがある。あるていど密閉した 槽内老照明する場合は、発熱の少ない照明灯を使っても、槽内 の温度の上昇は避けられない。この問題を解決するために、今 後は槽队の換気を考えて、改良しようと思う。

2 番目の問題点は、停電に対する不安である。こてで使った コンピューターは、瞬間的な停電によっても動作を停沚し、メ モリーの内容を失なう。そのために、停電後電源が復州しても 装置は完全に停此してしまう。この点に対して、現有の装置類 では効果的な対策を立てることができない。現在のところ、電 源の保守担当者と密接な連絡を取りながらこまめに運転状沅を 確認する以外、万法はない。

3 番目の問題点は、コンピューターの使用環境である。コン ピューターを塩分や湿度の高い環境に置くのは避けた方がよい。 飼育室はその点に関してまったく好ましくない環境である。試 運転中に極端に湿度が高い時に、湿度が原因と思わ机る異常が 起きた。その対策として、コンピューターとインターフェイス
を含むデジタル回路は、なるべく海水流しから離れたとてろに 置き、室内除湿するてとによって、少しでも良い環境で使え るように配慮した。そそれ以後、高湿度が原因と思われる恭常は 起こっていない。

\section{おわりに}

この装置は、潮間帯で起とっていることの一部分について再 現できるにすぎない。たとえば、波浪や水位の変化は、この装 置では再現できない。潮汐周期に応じた周期的な活動が、波浪 や水位の変化に支配されているならば、との装置によってその 活動の生理的な機構を解析するととはできない。だが、ヒザラ ガイの産甽に関しては、との装置で操作できる範用で解析でき るだろうと考えている。今後、この装置の問題点に対しては改 良を加えながら実験を進めていとうと思う。

稿をおさめるにあたって、以下の约謝意を表す。水槽を はじめとする塩ビ工作について、京都大学理学部付属瀬戸臨海 実験所の技官の方々に技術的な指導在頂いた。電子装㯰の部分 の設計と製作には、同実験所の院生・阿部直战氏の多大な協力 を得た。また、同実験所の助手・和田患忺先生、荒賀忠一先生 および阿部直哉氏にはこの原稿の校閲をお願いした。 